\title{
SOLAR ENERGY APPLICATION IN HOUSES HEATING SYSTEMS IN RUSSIA
}

\begin{abstract}
Dr. Zhanna Mingaleva, Perm National Research Polytechnic University, Perm, Russia, E-mail: mingal1@pstu.ru Dr. Natalia Vukovic, Ural Federal University, Yekaterinburg, Russia, E-mail: shpak@usfeu.ru Dr. Milan Radovanovic, Geographical Institute Jovan Cvijić SASA, Belgrade, Serbia/ Perm National Research Polytechnic University, Perm, Russia, E-mail: milan.geograf@gmail.com
\end{abstract}

ART I C LE INF O

Original Research

Received: March, 24.2017.

Revised: Jun, 05.2017.

Accepted: Jun, 09.2017.

doi:10.5937/IJCRSEE1701141M

UDK

620.91:523.9(470)

\section{Keywords:}

Solar Energy,

Alternative Source of Energy,

Energy Storage,

Energy Efficiency,

Russia.

\section{A B S T R A C T}

The solar energy is widely used around the world for electricity generation and heating systems in municipal services. But its use is complicated in the number of territories with uneven receipts of solar radiation on the earth's surface and large number of cloudy days during a year. A hypothesis on the possibility of application of individual solar collectors for heating of houses in the number of cities of Russia has been tested. The existing designs of solar collectors and checking the possibility of their application in northern territories of Russia are investigated. The analysis was carried out taking into account features of relief and other climatic conditions of the Perm and Sverdlovsk regions. As the result of research, the basic recommended conditions for application of solar batteries in houses of the northern Russian cities have been resumed.

(c) 2017 IJCRSEE. All rights reserved.

\section{INTRODUCTION}

It is very important to apply solar energy for a wide variety of applications and provide energy solutions by modifying the energy proportion, improving energy stability, increasing energy sustainability, conversion reduction and hence enhance the system efficiency. The present work aimed to study the application of solar energy systems in house heating.

During the previous research of Mingaleva, Z., and Shpak, N., 2015 it was revealed that in many Russian cities development of solar power production is inexpedient. The modern design of power generation of industrial solar installations is impossible in many regions of Russia because of uneven receipt of solar radiation on the earth's surface within a year, including Perm and Sverdlovsk Regions. In these regions all main restrictions of solar power use are mostly shown, they include the following:

Corresponding Author

Dr. Natalia Vukovic, Ural Federal University, Yekaterinburg, Russia, E-mail: shpak@usfeu.ru

\section{cc) (i) $\Theta$}

This work is licensed under a Creative Commons Attribution - NonCommercial - NoDerivs 4.0. The article is published with Open Access at www.ijcrsee.com
- seasonal distinctions in the day length; days;

- existence of a large number of cloudy

- high snow cover for a long time.

Now approaches to solar energy use in house construction are divided into types: active and passive Mingaleva, Z., and Shpak, N., 2015. The active approaches are based on using the solar energy batteries for production of heating and electrical energy, completely providing all needs of house inhabitants. The passive one is based on special arrangement of houses on districts, use of special designs, etc. The passive use of solar energy is applied generally in the southern regions, where sunlight is at maximum level and it is a constant within a year. In regions of a midland and northern territories, active use of solar energy is applied by solar batteries.

\section{MATERIALS AND METHODS}

The decision to test the hypothesis of economic feasibility of use of solar batteries for receipt of heat and electrical energy for residential and public buildings was made due to the availability of data on insolation amounts in the main regions of Russia and with breakdown for the summer/winter period. Calculations were carried out for four dates: On March 20, on June 21, on Septem- 
ber 22, on December 21, 2014 in astronomical midday when the maximum eminence of the Sun over the horizon is observed. Sun azimuth size makes $180^{\circ}$ at this time. Allocation of key points is made to determine the periods of effective use of solar batteries. For different latitudes astronomical midday falls on average at 13:00 local time.

On the basis of the comparative analysis method, the assessment of opportunities of the Russian cities to develop solar power at apartment houses is carried out. The study comprised the period covering the whole year and not just the key points of change. For calculations the data on solar statistics for 2014 were used. The calculations are made using "planetcalc.ru" system and the solar calculator. The data on the number of sunny days during a year, astronomical midday, angle between the plane and the direction of a stream of the solar energy are retrieved from statistic data during the time between sunrise and sunset. The data on efficiency of power return of the solar installation for apartment houses were used from Girard, A., Gago, E.J., 2015; Chiras, D. 2002; Badescu, V. 2003; Kaygusuz, K., Ayhan, T. 1999. According to this source, the highest coefficient of power return of the solar installation during a year can be achieved in case of its arrangement in the southern direction with an inclination $30^{\circ}-35^{\circ}$ to a horizontal surface. Calculations of coefficient of power return of solar installation in a year have shown that upon transition of winter months to summer reduction of possible heat constitutes about $1 \%$ for every $1^{\circ}$ deviation from a angle with the maximum effect. Therefore, for increase in a potential exit of heat during the winter period, especially when using for heating of the room, it is recommended that the collec-tor has been established on angle more than $15^{\circ}-20^{\circ}$ of the corresponding width. For example, the heating collector installation with slope $30^{\circ}$ even at $45^{\circ}$ of southwest direction gives nearly $95 \%$ of the optimal energy efficiency. Previous research has indicated that in certain situations - in regions with deep snow cover - it is recommended to establish a collector so that it will be not possible for snow to block the front part of the collector. Mathematical calculations of an optimum angle of an inclination of the solar panel are applied to determine the most effective volume of absorption of solar energy by the square of the solar battery by Emanuele Calabrò, 2013. The calculation of an ideal tilt angle for installation is carried out with use of results of the research conducted earlier by Chaturvedi, S.
K., Shen, J. Y. 1984; Siraki, A. G.; Pillay, P. 2012. Conclusions on the thermal efficiency of the cooker which have been received by on different conditions are taken from other research of Arabacigil, B., Yuksel N., Avci A. , 2015.

\section{RESULTS}

The choice of optimum orientation of the solar panels is one of the major questions at any type of the practical solar installation use. In the literature devoted to solar energy, this practical aspect is considered briefly. As it is known, the shading of surface directly influences the reflection coefficient of this surface. In case of solar batteries it determines the volume of the absorbed and reflected solar energy. For example, empirically for the glass established perpendicular to the solar stream the following sizes of reflection and absorption of solar energy are established (Table 1):

Table 1. Ratio of reflection coefficient and absorption of solar energy for glass (http:// dateandtime.info/ru, 2016)

\begin{tabular}{|c|c|c|c|}
\hline \multirow[t]{2}{*}{ Angle } & \multicolumn{2}{|c|}{$\begin{array}{c}\text { For a horizontal } \\
\text { surface }\end{array}$} & \multirow{2}{*}{$\begin{array}{c}\text { Effective } \\
\text { Panel } \\
\text { Square } \\
\text { in \% to the } \\
\text { real area }\end{array}$} \\
\hline & $\begin{array}{c}\text { Reflec- } \\
\text { tivity }\end{array}$ & $\begin{array}{c}\text { Transmission } \\
\text { factor }\end{array}$ & \\
\hline $0^{\circ}-30^{\circ}$ & $5 \%$ & $95 \%$ & $100 \%$ \\
\hline $30^{\circ}-60^{\circ}$ & $10 \%$ & $90 \%$ & $80-75 \%$ \\
\hline $60^{\circ}-70^{\circ}$ & $20 \%$ & $80 \%$ & $50 \%$ \\
\hline $70^{\circ}-80^{\circ}$ & $40 \%$ & $60 \%$ & $45-40 \%$ \\
\hline
\end{tabular}

These indicators are important for the choice of the placement of solar batteries in northern territories because during the winter period it is necessary to consider existence of snow cover and it is needed to clean the surface of batteries accepting radiation of snow.

The second factor which is necessary to consider making a choice of a tilt angle of solar batteries is concept of the effective area of the panel" - the radiation stream section blocked by the area of the panel.

The effective square of the panel is equal to the real area of the panel increased by a cosine of the angle between the direction of a stream and a perpendicular to the panel (or sine of the angle between its plane and the direction of a stream). Thus, if the panel is perpendicular to a stream, its effective area is 
equal to its real area, but if the stream is deviated from the perpendicular -it is equal to a half of the real area.

Thus, the essential deviation of a stream from a perpendicular to the panel not only increases reflection, but also reduces its effective area that leads to even more essential falling of the development coefficient of the solar battery. In these conditions the most effective continuous orientation of the solar panel is perpendicular to the stream of sunshine. However, it demands change of position of the panel in two following planes:

1) depending on the provision of the Sun in the sky during a day,

2 ) depending on the provision of the Sun in the sky on a year season.

Creation of such systems is technically feasible, however so far they turn out very difficult, expensive and not really reliable. Therefore, now the main research are conducted in the direction of search of the most optimum angle of the inclination of the solar panel in relation to the stream of sunshine in the stationary mode (without turn) or with one rotary mechanism.

Also it is necessary to consider a season in all calculations as for the different seasonal periods. As it is already noted, receipt of solar energy significantly differs. Respectively, also values of sine (cosines) of a angle between its plane and the direction of a stream will be various. So, for example, for Perm for 4 main dates: On March 20, on June 21, on Sep $h_{\Theta}$ nber 22, on December 21 in astronomical midday (the Sun azimuth $(\Psi)-180^{\circ}$ ) $\cos h_{\Theta}$ is 0.847 values; $0.567 ; 0.847$ and 0.988 respectively. The value of $\sin h_{\Theta}$ is according to $0.531,0.82,0.531$ and 0.148 respectively.

The calculations of the angle of the sun maximum rising over the horizon within a year for the cities of Russia (Appendix 1).

\section{DISCUSSIONS}

For the choice of the optimum angle of the solar panel inclination it is necessary to calculate the angle of the maximum raising of the Sun over the horizon within a year. For different geographical coordinates this difference will be a miscellaneous. The results of calculations for the cities of Russia are presented in the Table 2 (Appendix).

As it was already noted, calculations were carried out for four dates: On March 20, on June 21, on September 22, on December 21,2014 in astronomical midday when the maximum eminence of the Sun over the horizon is observed. Sun azimuth size makes $180^{\circ}$ at this time. For different latitudes astronomical midday falls on average on 12:00-13:00 local times.

Generally sunshine duration at the territory of Russia is between 1700 and 2000 hours per year. Only $1 / 3$ of its territory has sunshine duration, which is more than 2000 hours per year.

From the Table 2 we can see that only in 4 analyzed cities such as Vladivostok, Sochi, Astrakhan, Rostov-on-Don the duration of light day exceeds the necessary level for effective development of solar power generation during the whole year (8 hours in the winter).

It is also possible to include the Chita in this list of the Russian cities, in which it is possible to use solar collectors (panels) during the whole year round.

Chita is the leader among the Russian cities in quantity of sunny days during a year - it has 284sunny days per year (nearly $78 \%$ of year). It allows developing of solar energy even during the autumn and winter period with insignificant decline in production of solar batteries.

Time of rising and sunset gets to an interval of the greatest maximum of solar energy: from 9 to 15 hours. A large number of sunny days in a year are also in Omsk, however duration of light day is significantly lower in the winter. Therefore the unambiguous decision on expediency of year-round using of solar batteries in Omsk is not present.

It should be noted that there are solar collectors already allowing making heat even in cloudy weather that is applicable for many regions of Russia. In the number of Russian cities the experiment has already been made on transfer of solar power to heating systems and hot water production in apartment houses. The best European experience (Romanian, German, etc.) is implemented in the most advanced and sunny Russian cities such as Moscow, Sochi, Yekaterinburg, etc.

For example, in Yekaterinburg in the one of highrise apartment houses (Rodonitovaya St., 8), the vacuum solar collectors, absorbing the radiation of the sun at all seasons of the year, even in cloudy weather, are installed successfully. By calculations of experts, energy of the sun in the Ural has to be enough for heating of the building. The average day sum of the solar radiation in the region makes 2.9 kilowatt-hours on square meter whereas in Krasnodar this indicator is only a bit more than 3.5 
The main objective of experts is the definition of the correct tilt angle of the solar panel to provide the maximum receipt of the solar energy in a cold season.

Theoretical calculations showed that for all analyzed Russian cities the angle of the maximum raising of the Sun over the horizon within a year deviates average situation no more than on $\pm 23.5^{\circ}$ (the general difference between the maximum tilt angle and minimum makes $46.87^{\circ}$ ). Thus, as we already noted, the effective area of the panel at a deviation from a perpendicular ${ }^{\circ}$ remains on 23-24 rather big - about $90 \%$ of its real area.

Therefore for the analyzed cities it is possible to use the simplest option of increase of overall performance of the solar battery rotation of the solar battery only in one plane - round a polar axis of Earth with a speed of 1turn per day. The tilt angle of an axis of such rotation concerning a horizontal is equal to geographic latitude of a place.

It is necessary to organize the sliding connection allowing to take away all energy received by it, or to be limited to flexible communications with the fixed connection. But in both cases it is necessary to provide automatic return of the panel back at night from constantly rotating panel, otherwise it is not possible not to avoid twisting and break of the communications which are taking away energy.

Also both decisions sharply increase complexity and reduce reliability of system. In the case of increasing of power of panels' complexity, their sizes and weight, technical problems start to grow in a geometrical progression.

Already now are developed and applied the systems allowing tracing the provision of the Sun, solar tracker system. However, practically all of them are created for rather small weight and small windage of the turned panels. The horizontal placement of the solar panels in the whole territory of Russia is inefficient. Besides too big decrease in the development of the solar energy production during the autumn and winter period dust and snow are often accumulated on horizontal panels. It is possible to remove them from the batteries only by means of specially organized cleaning. If the inclination of the panel exceeds $60^{\circ}$, snow on its surface is late a little and is usually quickly showered by itself, and also the dust is well washed away by rains from its surface.

However, it is necessary to remember that panels with an inclination of $85^{\circ}$, almost vertically, after more or less considerable snowfall will not remain free from snow, especially if snow was though slightly sticky. The layer of this snow will be thinner. Usually on smooth surfaces (glass, plastic) with an inclination more than $60^{\circ}$ (a bias 2:1 and more) snow keeps from several hours to several days depending on weather in frosts. At the same time at a bias $40^{\circ}$ less snow can be late for the entire period of cold weather to the first thaw. If its volume will freeze, the snow cap can remain without cleaning till spring.

The choosing of tilt angle for solar panels in different Russian cities has been more detailed investigated (Table 2). Everything depends on the right time of exploitation of solar battery, if it is supposed to use solar batteries only during the spring and summer period. It is necessary to choose the optimum tilt angle, perpendicular to the average provision of the Sun during the period between spring and autumn equinoxes. If energy is generating all the year round, it is necessary "to squeeze out" a maximum in power scarce winter months, so, it is necessary to be guided by the average provision of the Sun between autumn and spring equinoxes and to place panels closer to a vertical on $5^{\circ}-15^{\circ}$ more than geographic latitude.

Results of calculations of a tilt angle of solar panels for the analyzed cities of Russia are given in the Table 3. 
Table 3. Calculations of a tilt angle of solar panels for the cities of Russia

\begin{tabular}{llcll}
\hline \multirow{2}{*}{ Cities } & \multicolumn{2}{c}{$\begin{array}{c}\text { Geographical } \\
\text { coordinates }\end{array}$} & $\begin{array}{c}\text { The recommended tilt } \\
\text { angle of the } \\
\text { solar panel }\end{array}$ \\
\cline { 2 - 5 } & $\begin{array}{c}\text { Geographic } \\
\text { latitude, } \\
\text { northern } \\
\text { latitude }\end{array}$ & $\begin{array}{c}\text { Geographical } \\
\text { longitude, } \\
\text { eastern } \\
\text { longitude }\end{array}$ & $\begin{array}{c}\text { Sping- } \\
\text { Summer } \\
\text { period }\end{array}$ & All year \\
\hline Vladivostok & $43^{\circ} 06^{\prime} 20^{\prime \prime}$ & $131^{\circ} 52^{\prime} 24^{\prime \prime}$ & $28^{\circ}-35^{\circ}$ & $48^{\circ}-58^{\circ}$ \\
\hline Sochi & $43^{\circ} 35^{\prime} 57^{\prime \prime}$ & $39^{\circ} 43^{\prime} 32^{\prime \prime}$ & $28^{\circ}-35^{\circ}$ & $48^{\circ}-58^{\circ}$ \\
\hline Astrakhan & $46^{\circ} 20^{\prime} 58^{\prime \prime}$ & $48^{\circ} 02^{\prime} 26^{\prime \prime}$ & $31^{\circ}-36^{\circ}$ & $51^{\circ}-61^{\circ}$ \\
\hline Rostov & $47^{\circ} 13^{\prime} 52^{\prime \prime}$ & $39^{\circ} 43^{\prime} 23^{\prime \prime}$ & $32^{\circ}-37^{\circ}$ & $52^{\circ}-62^{\circ}$ \\
\hline -on-Don & $52^{\circ} 01^{\prime} 54^{\prime \prime}$ & $113^{\circ} 30^{\prime} 03^{\prime \prime}$ & $37^{\circ}-42^{\circ}$ & $57^{\circ}-67^{\circ}$ \\
\hline Chita & $53^{\circ} 01^{\prime} 00^{\prime \prime}$ & $158^{\circ} 39^{\prime} 00^{\prime \prime}$ & $38^{\circ}-43^{\circ}$ & $58^{\circ}-68^{\circ}$ \\
\hline $\begin{array}{l}\text { The } \\
\text { Petropavlovsk } \\
\text {-Kamchatsky }\end{array}$ & $54^{\circ} 59^{\prime} 32^{\prime \prime}$ & $73^{\circ} 22^{\prime} 06^{\prime \prime}$ & $39^{\circ}-44^{\circ}$ & $60^{\circ}-70^{\circ}$ \\
\hline Omsk & $55^{\circ} 02^{\prime} 29^{\prime \prime}$ & $82^{\circ} 56^{\prime} 04^{\prime \prime}$ & $40^{\circ}-45^{\circ}$ & $60^{\circ}-70^{\circ}$ \\
\hline Novosibirsk & $55^{\circ} 45^{\prime} 07^{\prime \prime}$ & $37^{\circ} 36^{\prime} 56^{\prime \prime}$ & $41^{\circ}-46^{\circ}$ & $61^{\circ}-71^{\circ}$ \\
\hline Moscow & $56^{\circ} 51^{\prime} 06^{\prime \prime}$ & $60^{\circ} 36^{\prime} 43^{\prime \prime}$ & $41^{\circ}-46^{\circ}$ & $62^{\circ}-72^{\circ}$ \\
\hline Yekaterinburg & $58^{\circ} 00^{\prime} 37^{\prime \prime}$ & $56^{\circ} 15^{\prime} 00^{\prime \prime}$ & $43^{\circ}-48^{\circ}$ & $62^{\circ}-72^{\circ}$ \\
\hline Perm & $59^{\circ} 56^{\prime} 19^{\prime \prime}$ & $30^{\circ} 18^{\prime} 50^{\prime \prime}$ & $45^{\circ}-50^{\circ}$ & $65^{\circ}-75^{\circ}$ \\
\hline St. Petersburg & $61^{\circ} 47^{\prime} 05^{\prime \prime}$ & $34^{\circ} 20^{\prime} 48^{\prime \prime}$ & $47^{\circ}-52^{\circ}$ & $67^{\circ}-77^{\circ}$ \\
\hline Petrozavodsk & $64^{\circ} 32^{\prime} 24^{\prime \prime}$ & $40^{\circ} 32^{\prime} 35^{\prime \prime}$ & $49^{\circ}-54^{\circ}$ & $69^{\circ}-79^{\circ}$ \\
\hline Arkhangelsk & & & \\
\hline
\end{tabular}

If for architectural or constructive reasons it is impossible to sustain such angle and it is necessary to choose between a tilt angle in $40^{\circ}$ less or vertical installation, for year-round use it is necessary to prefer vertical situation. Thus energy "shortage" in long summer days is not so critical, during this period people's demand in heating and electricity are not high, and the need for development of energy is usually not so great, as in the winter and in off-season.

\section{CONCLUSIONS}

In the course of research it was revealed that solar installations can be useful in a midland and even in many more than northern areas. In Perm and Sverdlovsk Regions during long days, at least half a year between spring and to autumn equinoxes, they are quite effective.

The main directions of use of solar collectors in Perm and Sverdlovsk Regions are production of low energy for heating of rooms, and also application of solar installations for actuating of conditioners during the hot summer period which is rather long and a little comfortable in all large cities of Russia.

Thus, our conclusions concerning the arrangement of the solar collector position are the following: the collector has to be located properly for providing free pass of sunshine from 9 to 15 hours since at this time solar energy is at maximum.

It is expedient to establish a collectorfaced to the south at an angle corresponding to installation width. It is possible to have variations in productivity till 20 degrees from the south since they do not influence the productivity of heat of a collector. In houses it is necessary to apply the combined power sources for generation of heating and electricity.

The main direction of current research is to clarify the most optimum, effective and the least expensive combinations of various energy carriers for ensuring heat, hot water and the electric power in residential and office buildings of the Russian cities located in a midland and more northern areas.

\section{ACKNOWLEDGEMENTS}

The work is carried out based on the task on fulfilment of government contractual work in the field of scientific activities as a part of base portion of the state task of the Ministry of Education and Science of the Russian Federation to Perm National Research Polytechnic University (the topic \# 26.6884.2017/8.9 "Sustainable development of urban areas and the improvement of the human environment"). 


\section{NOMENCLATURE}

$\Psi \quad$ sun azimuth, $\left[{ }^{\circ}\right]$

$h_{\Theta}$ angle between the plane and the direction of a stream of solar energy, $\left[{ }^{\circ}\right]$ $\cos h_{\Theta} \cos$ of angle between the plane and the direction of a stream of solar energy, [-] $\sin h_{\Theta} \sin$ of angle between the plane and the direction of a stream of solar energy, [-]

\section{REFERENCES}

Arabacigil, B., Yuksel, N., \& Avci, A. (2015). The use of paraffin wax in a new solar cooker with inner and outer reflectors. Thermal Science, 19(5), 16631671. https://doi.org/10.2298/TSCI121022031A

Badescu, V., \& Sicre, B. (2003). Renewable energy for passive house heating: II. Model. Energy and buildings, 35(11), 1085-1096. https://doi. org/10.1016/j.enbuild.2003.09.004

Calabrò, E. (2013). An algorithm to determine the optimum tilt angle of a solar panel from global horizontal solar radiation. Journal of Renewable Energy, 2013. http://dx.doi. org/10.1155/2013/307547

Chaturvedi S.K., Shen J.Y. (1984). Thermal performance of a direct expansion solar-assisted heat pump. Solar Energy, 2, 155-162. https://doi. org/10.1016/0038-092X(84)90233-0

Chiras, D. D. (2002). The solar house: passive heating and cooling. Chelsea Green Publishing. https:// goo.gl/7v4Oud

Girard, A., Gago, E. J., Muneer, T., \& Caceres, G. (2015). Higher ground source heat pump COP in a residential building through the use of solar thermal collectors. Renewable energy, 80, 26-39. https://doi.org/10.1016/j.renene.2015.01.063

Kaygusuz, K., \& Ayhan, T. (1999). Experimental and theoretical investigation of combined solar heat pump system for residential heating. Energy Conversion and Management, 40(13), 1377-1396. https://doi.org/10.1016/S01968904(99)00026-6

Mingaleva, Z., \& Shpak, N. (2015). Possibilities of solar energy application in Russian cities. Thermal Science, 19(suppl. 2), 457-466. https://doi. org/10.2298/TSCI150330087M

Siraki, A. G., \& Pillay, P. (2012). Study of optimum tilt angles for solar panels in different latitudes for urban applications. Solar energy, 86(6), 1920-1928. https://doi.org/10.1016/j.solener.2012.02.030 


\section{Appendix 1}

Table 2. Calculations of the angle of the Sun maximum rising over the horizon within a year for the cities of Russia

\begin{tabular}{|c|c|c|c|c|c|}
\hline Date & 20 of March & 21 of June & $\begin{array}{l}22 \text { of Sep- } \\
\text { tember }\end{array}$ & $\begin{array}{l}21 \text { of Decem- } \\
\text { ber }\end{array}$ & $\begin{array}{l}\text { Number of } \\
\text { sunny days in } \\
\text { a year }\end{array}$ \\
\hline W(Sun azimuth) & $180^{\circ}$ & $180^{\circ}$ & $180^{\circ}$ & $180^{\circ}$ & \\
\hline \multicolumn{6}{|c|}{ Vladivostol ( $43^{\circ} 06^{\prime} 20^{\prime \prime}$ northern latitude) } \\
\hline Astronomical midday & $13: 20$ & $13: 14$ & $13: 05$ & $13: 10$ & 269 \\
\hline $\begin{array}{l}\text { Duration of light day. } \\
\text { hourg }\end{array}$ & $\begin{array}{l}46.61 \\
12 \mathrm{~h} 7 \mathrm{~m} 46 \mathrm{~s}\end{array}$ & $\begin{array}{l}70.32 \\
15 \mathrm{~h} 22 \mathrm{~m} 375\end{array}$ & $\begin{array}{l}47.31 \\
12 \mathrm{~h} 12 \mathrm{~m} 05\end{array}$ & $\begin{array}{l}23.45 \\
\text { Sh } 59 \mathrm{~m} 375\end{array}$ & \\
\hline Sunrise & $8: 16$ & $6: 32$ & $7: 59$ & $8: 40$ & \\
\hline Sunset & $20: 23$ & $21: 55$ & $20: 11$ & $17: 40$ & \\
\hline \multicolumn{6}{|c|}{ Sochi ( $43^{\circ} 35^{\prime} 57^{\prime \prime}$ northern latitude) } \\
\hline Astronomical midday & 1228 & 1222 & 1213 & 1219 & 190 \\
\hline & 46.12 & 69.84 & 46.83 & 22.97 & \\
\hline $\begin{array}{l}\text { Duration of light day. } \\
\text { hours }\end{array}$ & $12 \mathrm{~h} 9 \mathrm{~m} 28 \mathrm{~s}$ & $15 \mathrm{~h} 26 \mathrm{~m} 185$ & $12 \mathrm{~h} 10 \mathrm{~m} 30 \mathrm{~s}$ & $8 \mathrm{~h} 56 \mathrm{~m} 10 \mathrm{~s}$ & \\
\hline Sunrige & $7: 23$ & $5: 39$ & $7: 08$ & $7: 51$ & \\
\hline Sunset & $19: 33$ & $21: 06$ & $19: 19$ & $16: 47$ & \\
\hline \multicolumn{6}{|c|}{ Astrakhan ( $46^{\circ} 20^{\prime} 58^{\prime \prime}$ northern latitude) } \\
\hline Astronomical midday & 1155 & 1149 & 1140 & 1146 & 259 \\
\hline & 43.39 & 67.10 & 44.09 & 20.23 & \\
\hline $\begin{array}{l}\text { Duration of light day, } \\
\text { hours }\end{array}$ & $12 \mathrm{~h} 9 \mathrm{~m} 525$ & $15 \mathrm{~h} 48 \mathrm{~m} 18 \mathrm{~s}$ & $12 \mathrm{~h} 11 \mathrm{~m} 95$ & $8 \mathrm{~h} 35 \mathrm{~m} 48 \mathrm{~s}$ & \\
\hline Sunrise & $6: 50$ & $4: 55$ & $6: 34$ & $7: 28$ & \\
\hline Sunset & $19: 00$ & $20: 43$ & $18: 46$ & $16: 03$ & \\
\hline \multicolumn{6}{|c|}{ Rostov-on-Don $\left(47^{\circ} 13^{\prime} 52^{\prime \prime}\right.$ northern latitude) } \\
\hline Astronomical midday & 1228 & 1222 & 1213 & 1219 & 199 \\
\hline & 42.49 & 66.20 & 43.19 & 19.33 & \\
\hline $\begin{array}{l}\text { Duration of light day. } \\
\text { hourg }\end{array}$ & $12 \mathrm{~h} 13 \mathrm{~m} 32 \mathrm{~s}$ & $15 \mathrm{~h} 55 \mathrm{~m} 57 \mathrm{~s}$ & $12 \mathrm{~h} 11 \mathrm{~m} 17 \mathrm{~g}$ & $8 \mathrm{~h} 28 \mathrm{~m} 45 \mathrm{~s}$ & \\
\hline Sunrige & $7: 21$ & $5: 24$ & $7: 08$ & $8: 04$ & \\
\hline Sunset & $19: 35$ & $21: 20$ & $19: 19$ & $16: 33$ & \\
\hline \multicolumn{6}{|c|}{ Chita (52 $2^{\circ} 01^{\prime} 54^{\prime \prime}$ northern latitude) } \\
\hline Astronomical midday & 1333 & 1327 & 1318 & 1323 & 284 \\
\hline & 37.69 & 61.40 & 38.78 & 14.53 & \\
\hline $\begin{array}{l}\text { Duration of light day. } \\
\text { hourg }\end{array}$ & $12 \mathrm{~h} 9 \mathrm{~m} \mathrm{20s}$ & $16 \mathrm{~h} 44 \mathrm{~m} 325$ & $12 \mathrm{~h} 14 \mathrm{~m} 215$ & $7 \mathrm{~h} 44 \mathrm{~m} 285$ & \\
\hline Sunrige & $8: 28$ & $6: 05$ & 8:11 & $8: 31$ & \\
\hline Sunset & $20: 38$ & $22: 49$ & $20: 25$ & $16: 16$ & \\
\hline \multicolumn{6}{|c|}{ The Petroparlorsle-Kamchatsky ( $53^{\circ} 01^{\prime} 00^{\prime \prime}$ northern latitude) } \\
\hline Astronomical midday & 1333 & 1327 & 1318 & 1323 & 47 \\
\hline & 36.61 & 60.42 & 37.51 & 13.55 & \\
\hline $\begin{array}{l}\text { Duration of light day. } \\
\text { hours }\end{array}$ & $12 \mathrm{~h} 8 \mathrm{~m} 39 \mathrm{~s}$ & $16 \mathrm{~h} 56 \mathrm{~m} 395$ & $12 \mathrm{~h} 15 \mathrm{~m} 36 \mathrm{~s}$ & $7 \mathrm{~h} 33 \mathrm{~m} 345$ & \\
\hline Sunrise & $7: 28$ & $4: 58$ & $7: 10$ & $9: 36$ & \\
\hline Sunset & $19: 37$ & $21: 55$ & $19: 26$ & $17: 10$ & \\
\hline \multicolumn{6}{|c|}{ Omsk ( $54^{\circ} 39^{\prime} 32^{\prime \prime}$ northern latitude) } \\
\hline Astronomical midday & 1314 & 1308 & 1259 & 1304 & 223 \\
\hline
\end{tabular}


(IJCRSEE) International Journal of Cognitive Research in Science, Engineering and Education Vol. 5, No.1, 2017.

\begin{tabular}{|c|c|c|c|c|c|}
\hline Date & 20 of March & 21 of June & $\begin{array}{l}22 \text { of Sep- } \\
\text { tember }\end{array}$ & $\begin{array}{l}21 \text { of Decem- } \\
\text { ber }\end{array}$ & $\begin{array}{l}\text { Number of } \\
\text { sunny days in } \\
\text { a year }\end{array}$ \\
\hline Sunset & $20: 19$ & $22: 49$ & $20: 06$ & $16: 39$ & \multirow{6}{*}{298} \\
\hline \multicolumn{6}{|c|}{ Novosibirsk ( $55^{\circ} 02$ '29" northern latitude) } \\
\hline Astronomical midday & 1235 & 1230 & 1221 & 1226 & \\
\hline$h_{\square}$ & 34.69 & 58.40 & 35.39 & 11.53 & \\
\hline Duration of light day. & $12 \mathrm{~h} 10 \mathrm{~m} 54 \mathrm{~s}$ & $17 \mathrm{~h} 23 \mathrm{~m} 13 \mathrm{~s}$ & $12 \mathrm{~h} 145$ & $7 \mathrm{~h} 9 \mathrm{~m} 47 \mathrm{~g}$ & \\
\hline Sunrise & $7: 30$ & $4: 48$ & $7: 13$ & $8: 51$ & \\
\hline Sunset & 19:41 & $22: 11$ & $19: 28$ & $16: 01$ & \\
\hline \multicolumn{6}{|c|}{ Moscow ( $55^{\circ} 45^{\prime} 07^{\prime \prime}$ northern latitude) } \\
\hline Astronomical midday & 1236 & 1231 & 1222 & 1227 & \multirow[t]{5}{*}{114} \\
\hline & 33.97 & 57.69 & 34.68 & 10.82 & \\
\hline $\begin{array}{l}\text { Duration of light day. } \\
\text { hourg }\end{array}$ & $12 \mathrm{~h} 16 \mathrm{~m} 535$ & $17 \mathrm{~h} 33 \mathrm{~m} 39 \mathrm{~s}$ & $12 \mathrm{~h} 13 \mathrm{~m} 465$ & $7 \mathrm{~h} \mathrm{Om} \mathrm{31s}$ & \\
\hline Sunrige & $7: 28$ & $4: 44$ & $7: 15$ & $8: 57$ & \\
\hline Sunset & 19:45 & $22: 18$ & $19: 29$ & $15: 57$ & \\
\hline \multicolumn{6}{|c|}{ Yekaterinburg ( $56^{\circ} 51^{\prime} 06^{\prime \prime}$ northern latitude) } \\
\hline $\begin{array}{l}\text { Astronomical midday } \\
\hat{h}_{\square}\end{array}$ & $\begin{array}{l}1305 \\
32.89\end{array}$ & $\begin{array}{l}1259 \\
56.60\end{array}$ & $\begin{array}{l}1250 \\
33.59\end{array}$ & $\begin{array}{l}1255 \\
9.73\end{array}$ & 150 \\
\hline $\begin{array}{l}\text { Duration of light day. } \\
\text { hours }\end{array}$ & $12 \mathrm{~h} 11 \mathrm{~m} 53 \mathrm{~s}$ & $17 \mathrm{~h} 5 \operatorname{lm} 55$ & $12 \mathrm{~h} 14 \mathrm{~m} 545$ & $6 \mathrm{~b} 45 \mathrm{~m} 125$ & \\
\hline Sunrige & $7: 59$ & $5: 03$ & $7: 42$ & $9: 33$ & \\
\hline Sunset & $20: 10$ & $22: 54$ & $19: 57$ & $16: 18$ & \\
\hline \multicolumn{6}{|c|}{ Perm (58'00'37" northern latitude) } \\
\hline Astronomical midday & 1322 & 1316 & 1307 & 1313 & 145 \\
\hline & 31.71 & 55.42 & 32.41 & 8.55 & \\
\hline $\begin{array}{l}\text { Duration of light day. } \\
\text { hours }\end{array}$ & $12 \mathrm{~h} 12 \mathrm{~m} 20 \mathrm{~s}$ & $18 \mathrm{~h} 11 \mathrm{~m} \mathrm{21s}$ & $12 \mathrm{~h} 15 \mathrm{~m} 215$ & $6 \mathrm{~h} 27 \mathrm{~m} 335$ & \\
\hline Sunrige & $8: 16$ & 5:11 & $8: 00$ & $9: 59$ & \\
\hline Sunset & $20: 28$ & $23: 22$ & $20: 15$ & $16: 26$ & \\
\hline \multicolumn{6}{|c|}{ St. Petersburg ( $59^{\circ} 56^{\prime} 19^{\prime \prime}$ northern latitude) } \\
\hline Astronomical midday & 1306 & 1300 & 1251 & 1256 & 105 \\
\hline$h_{\text {Duration of liskt dav }}$ & 29.77 & 53.49 & 30.48 & 6.62 & \\
\hline hours & & & & & \\
\hline Sunrige & $7: 59$ & $4: 35$ & $7: 43$ & $10: 00$ & \\
\hline Sunset & $20: 13$ & $23: 26$ & $19: 59$ & $15: 53$ & \\
\hline \multicolumn{6}{|c|}{ Petrozavodsk ( $61^{\circ} 47^{\prime} 05^{\prime \prime}$ northern latitude) } \\
\hline $\begin{array}{l}\text { Astronomical midday } \\
h_{\square}\end{array}$ & $\begin{array}{l}1250 \\
27.94\end{array}$ & $\begin{array}{l}1244 \\
51.55\end{array}$ & $\begin{array}{l}1235 \\
28.64\end{array}$ & $\begin{array}{l}1240 \\
4.78\end{array}$ & 16 \\
\hline $\begin{array}{l}\text { Duration of light day. } \\
\text { hours }\end{array}$ & $12 \mathrm{~h} 14 \mathrm{~m} 395$ & $19 \mathrm{~h} 38 \mathrm{~m} 49 \mathrm{~s}$ & $12 \mathrm{~h} 16 \mathrm{~m} 285$ & $5 \mathrm{~h} 14 \mathrm{~m} 35 \mathrm{~s}$ & \\
\hline Sunrise & $7: 42$ & $3: 55$ & $7: 27$ & $10: 03$ & \\
\hline Sunset & $19: 57$ & $23: 33$ & $19: 43$ & $15: 18$ & \\
\hline \multicolumn{6}{|c|}{ Arkhangelsk ( $64^{\circ} 32^{\prime} 24^{\prime \prime}$ northern latitude) } \\
\hline Astronomical midday & 1225 & 1220 & 1210 & 1216 & 108 \\
\hline & 25.17 & 48.89 & 25.88 & 2.02 & \\
\hline $\begin{array}{l}\text { Duration of light day. } \\
\text { hourg }\end{array}$ & $12 \mathrm{~h} 15 \mathrm{~m} 59 \mathrm{~s}$ & $2 \ln 3 \operatorname{lm} 26 \mathrm{~s}$ & $12 \mathrm{~h} 18 \mathrm{~m} 17 \mathrm{~s}$ & $3 \mathrm{~h} 53 \mathrm{~m} 48 \mathrm{~s}$ & \\
\hline Sunrige & $7: 17$ & $2: 33$ & $7: 01$ & $10: 19$ & \\
\hline Sunset & 19:33 & $0: 05$ & $19: 19$ & $14: 12$ & \\
\hline
\end{tabular}

